\title{
New Organic-Mineral Fertilizer Based on Low-Grade Phosphorites and Microflora of Activated Sludge
}

\author{
N. A. Doniyarov ${ }^{1}$, I. A. Tagaev ${ }^{1}$, M. N. Muratova $^{1}$, and L. S. Andriyko ${ }^{2}$ \\ ${ }^{1}$ Navoi State Mining Institute, \\ 27 a Galaba Ave., \\ 210100 Navoiy, Uzbekistan \\ ${ }^{2}$ Chuiko Institute of Surface Chemistry, N.A.S. of Ukraine, \\ 17, General Naumov Str., \\ UA-03164 Kyiv, Ukraine
}

The possibility of transforming a phosphorite rock containing less than $10 \%$ $\mathrm{P}_{2} \mathrm{O}_{5}$ into a full-fledged organic-mineral nitrogen-phosphorus multielement fertilizer with subsequent disinfection of the obtained product is determined. $\mathrm{X}$-ray fluorescent analysis of phosphorites shows that its microelement composition in quantitative terms coincides with the plant one, and therefore, applying this fertilizer, the plant can get all the necessary minor nutrient elements. As revealed, for the samples with the liquid phase, microorganisms have the high activity in comparison with the control variants that is associated with the impact of a biogenic factor only. The ability of microorganisms of activated sludge to degrade insoluble compounds of phosphorite ore and slime and to transform their insoluble form into soluble one is shown. The process flow diagram and points of the addition of low-grade phosphorites and phosphorite slime to the primary and secondary sedimentation tanks tested at the operating biochemical treatment station are given. Thus, the obtained solid condensed deposits from low-grade phosphorites and sludge will contain up to $18-22 \% \mathrm{P}_{2} \mathrm{O}_{5}, 12-14 \%$ nitrates and nitrites, $4-5 \% \mathrm{~K}_{2} \mathrm{O}$, and $\mathrm{CaO}$ and $\mathrm{MgO}$, which are digestible together with the accompanying set of all trace elements by plants.

Визначено можливість перетворення фосфоритової породи, що містить менше $10 \% \quad \mathrm{P}_{2} \mathrm{O}_{5}$, у повноцінне органо-мінеральне азотно-фосфорне багатоелементне добриво 3 подальшою дезінфекцією одержаного продукту. Рентґенофлюоресцентна аналіза фосфоритів показала, що його мікроелементний склад в кількісному вираженні подібний до рослинного, а отже, застосовуючи це добриво, рослина може отримувати всі необхідні поживні мікроелементи. Виявлено, що для зразків із рідкою фазою мікроорганізми мають високу активність порівняно з контрольними варіянтами, що пов’язане лише з впливом біогенного чинника. По- 
казано здатність мікроорганізмів активного мулу піддавати деградації нерозчинні сполуки руди і шламу та трансформувати їх з нерозчинної форми в розчинну. Наведено технологічну схему та точки внесення низькосортних фосфоритів і шламу в первинні та вторинні відстійники, апробовані на діючій станції біохемічної очистки. Таким чином, одержані тверді конденсовані відкладення 3 низькосортних фосфоритів i шламу матимуть до $18-22 \% \quad \mathrm{P}_{2} \mathrm{O}_{5}, 12-14 \%$ нітратів і нітритів, 4-5\% $\mathrm{K}_{2} \mathrm{O}$, а також $\mathrm{CaO}$ та $\mathrm{MgO}$, що засвоюються рослинами разом із супутнім набором всіх мікроелементів.

Key words: activated sludge, low-grade phosphorite, slime, fertilizer, microflora.

Ключові слова: активний мул, низькосортні фосфорити, шлам, добриво, мікрофлора.

(Received 22 June, 2020)

\section{INTRODUCTION}

The Republic of Uzbekistan is a country of intensive consumption of phosphorus fertilizers. The problem of creating the new types of complex organic fertilizer with increased agro-ecological value and efficiency is currently relevant. The use of complex fertilizers containing a complete set of both macro- and micronutrients will significantly improve the productivity of agricultural production and product quality. On the other hand, this will significantly reduce the dose of fertilizer, balance the ratio of nutrients, and reduce the technological costs of their application and storage.

Many naturally occurring wastes can be used as secondary raw materials for the production of fertilizers, as well as means to increase of land productivity and crop yields. Among such types of organic waste, livestock waste (cattle manure, bird droppings), crop production, as well as industrial production (low-grade phosphorite of Central Kyzyl-Kum) can be highlighted. It should be noted that, at the Kyzyl-Kum Phosphoritic Plant (KPP) of Navoi Mining and metallurgical Combine (NMMC), during the enrichment of highly carbonated phosphorites of the Central Kyzyl-Kum, waste is formed in the form of off-balance ore with a content of $13-15 \% \quad \mathrm{P}_{2} \mathrm{O}_{5}$ and sludge phosphorites with a content of $8-12 \% \quad \mathrm{P}_{2} \mathrm{O}_{5}$ [1-7]. The total volume of accumulated waste phosphorites has already reached about 13 million tons.

At present, there is an acute question of finding new rational ways of processing low-grade phosphorites of the Central KyzylKum region into high-quality phosphorus-containing fertilizers.

The aim of this work is the usage of microflora of activated 
sludge from biochemical treatment plants for municipal waste as an alternative for the recycling of low-grade phosphorite ores. For this, low-grade phosphorites and waste from the Kyzyl-Kum Phosphoritic Plant (KPP) of NMMC were taken as initial materials for obtaining a new type of organic-mineral fertilizer enriched with phosphorus and activated sludge. This makes it possible to transform phosphorite rock containing less than $10 \% \quad \mathrm{P}_{2} \mathrm{O}_{5}$ into a fullfledged organic-mineral nitrogen-phosphorus multielement fertilizer with subsequent disinfection of the obtained product.

An achievement of such a result is possible by transforming the indigestible $\mathrm{P}_{2} \mathrm{O}_{5}$ form to a form that is digestible for plants using the microflora of sewage treatment plants [8-12].

Thus, the objective of the present study was to study the chemical composition and microflora of activated sludge from the biochemical cleaning plant of JSC Navoiazot and low-grade phosphorite rock from KPP NMMC, resulting from the addition of both lowgrade ore and phosphorite wastes into the aerotanks of the station.

\section{MATERIALS AND METHODS}

Laboratory studies on the destruction of various types of minerals from low-grade phosphate of KPP NMMC using aerobic types of neutrophilic microorganisms of AS of the biochemical cleaning plant of JSC Navoiazot were carried out at the Navoi State Mining Institute.

The object of the study was low-grade phosphorite ore and sludge from KPP NMMC with the following chemical composition (Tables 1, 2) similar to [13].

Analyses of the chemical composition of activated sludge and variants with a mineralized mass and phosphorite slime were performed at the Research Institute of General and Inorganic Chemistry of the Academy of Sciences of the Uzbekistan Republic.

For the cultivation of aerobic microorganisms of activated sludge

TABLE 1. The chemical composition of phosphorites of the Central KyzylKum.

\begin{tabular}{c|c|c|c|c|c}
\hline No. & $\begin{array}{c}\text { Compound } \\
\text { name }\end{array}$ & $\begin{array}{c}\text { Elements } \\
\text { content, \% }\end{array}$ & No. & $\begin{array}{c}\text { Compound } \\
\text { name }\end{array}$ & $\begin{array}{c}\text { Elements } \\
\text { content, \% }\end{array}$ \\
\hline 1 & $\mathrm{P}_{2} \mathrm{O}_{5}$ & $8-12.2$ & 7 & $\mathrm{CO}_{2}$ & $8-15$ \\
2 & $\mathrm{Al}_{2} \mathrm{O}_{3}$ & $1.5-3.0$ & 8 & Fluorine & $1.8-3.2$ \\
3 & $\mathrm{SiO}_{2}$ & $6.0-8.0$ & 9 & $\mathrm{SO}_{3}$ & $2.5-3.5$ \\
4 & $\mathrm{CaO}$ & $42-48.1$ & 10 & $\mathrm{H}_{2} \mathrm{O}$ & 10.0 \\
5 & $\mathrm{MgO}$ & $2.5-3.5$ & 11 & Organic substance & $2.8-3.0$ \\
6 & $\mathrm{Fe}_{2} \mathrm{O}_{3}$ & $0.6-0.8$ & 12 & Insoluble residue & $8.0-8.2$ \\
\hline
\end{tabular}


TABLE 2. Chemical composition of activated sludge from the shop of biochemical cleaning of JSC Navoiazot.

\begin{tabular}{c|c|c|c|c|c|c|c|c}
\hline \multicolumn{7}{c}{ Composition of activated sludge, \% } \\
\hline Moisture & $\begin{array}{c}\text { Organic } \\
\text { substances }\end{array}$ & Nitrogen & $\mathrm{P}_{2} \mathrm{O}_{5}$ & $\mathrm{~K}_{2} \mathrm{O}$ & $\mathrm{CaO}$ & $\mathrm{MgO}$ & Ash & $\begin{array}{c}\text { Dry } \\
\text { weight }\end{array}$ \\
\hline 95.38 & 2.99 & 0.12 & 0.14 & 0.01 & 0.17 & 0.02 & 1.41 & 4.67 \\
\hline \multicolumn{7}{c}{ In conversion to oven-dry basis, \% } \\
\hline 10.05 & 28.54 & 11.44 & 13.35 & 0.95 & 16.21 & 1.90 & 13.44 & 44.26 \\
\hline
\end{tabular}

involved in the processing ore and slime of phosphorites, reactors were created, resembling in their design aerotanks. 500 grams of phosphorite ore or slime per 2 litres of the liquid phase or solid precipitate of activated sludge were loaded into these reactors with the same ratio. In other words, the ratio of solid $(S)$ to liquid $(L)$ $S: L=1: 4$ was completed.

The following variants for ore and sludge are drawn up (Table 3).

The reactor, created in the laboratory, simulated the processes occurring in the aeration tanks. Variants for the interaction of activated sludge with phosphorites were kept for 14 days.

In variants of the samples, the total content of $\mathrm{P}_{2} \mathrm{O}_{5}$, digestible by Trilon $\mathrm{B}$ and in $2 \%$ citric acid solution was determined according to a known method described in detail [14]. Studies were carried out according to GOSTs: ash content in line with GOST 26714-85, humidity in line with GOST 26712-94, organic substance content in line with GOST 27980-80 [15-17]. The solid phase (after the separation of alkaline-soluble organic substances from it) is the final decomposition product of organic substances. It was thoroughly washed with distilled water and then dried to a constant weight, and the yield of organic compound was determined.

After bacterial leaching out for 14 days, samples of the liquid and solid phases were sent to the State Unitary Enterprise 'Uzbek Research and Development and Survey Institute of Geology and Nonferrous Metallurgy' ('UzGEORANGMETLITI') for study-

TABLE 3. Variants of experiments on phosphorite ore and slime.

\begin{tabular}{|c|c|c|c|c|c|c|}
\hline $\begin{array}{c}\text { Variants } \\
\text { title }\end{array}$ & $\begin{array}{c}\text { Ratio } \\
S: L\end{array}$ & Variant 1 & Variant 2 & Variant 3 & Variant 4 & Variant 5 \\
\hline $\begin{array}{c}\text { Phosphorite } \\
\text { ore }(\mathrm{PhO}) \\
\end{array}$ & $1: 4$ & Water $+\mathrm{PhO}$ & 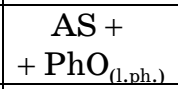 & $\begin{array}{l}\mathrm{AS}_{(\text {s.res.) }}+ \\
+ \text { PhO }\end{array}$ & $\begin{array}{c}\mathrm{AS}_{\text {(1.ph.) }}+ \\
+\mathrm{PhO}+\mathrm{O}_{2} \\
\end{array}$ & $\begin{array}{l}\mathrm{AS}_{\text {(s.res.) }}+ \\
\mathrm{PhO}+\mathrm{O}_{2}\end{array}$ \\
\hline \multirow[b]{2}{*}{$\begin{array}{l}\text { Phosphorite } \\
\text { slime (Sl) }\end{array}$} & \multirow[b]{2}{*}{$1: 4$} & Variant 6 & Variant 7 & Variant 8 & Variant 9 & Variant 10 \\
\hline & & Water $+\mathrm{Sl}$ & $\mathrm{AS}+\mathrm{Sl}_{(1 . \mathrm{ph} .)}$ & $\mathrm{AS}_{\text {(s.res.) }}+\mathrm{Sl}$ & $\begin{array}{l}\mathrm{AS}_{(\mathrm{l} . \mathrm{ph} .)}+ \\
+\mathrm{Sl}+\mathrm{O}_{2}\end{array}$ & $\begin{array}{c}\mathrm{AS}_{(\text {s.res.) }}+ \\
+\mathrm{Sl}+\mathrm{O}_{2}\end{array}$ \\
\hline
\end{tabular}

Note: 1.ph.—liquid phase, s.res.—-solid residue. 
ing by an universal x-ray fluorescent energy-dispersive spectrometer BRA-135F, which allows us to determine simultaneously more than two dozen chemical elements during a time not exceeding 300 seconds in a wide range of concentrations ranging from hundreds to ppb. BRA-135F analyses samples in the solid, powdery, and liquid states, as well as deposited on the surface or the filters.

\section{RESULTS AND DISCUSSION}

Kyzyl-Kum phosphorites consist mainly of phosphoritized faunal residues bonded with fine-grained calcite cement [18, 19]. Foraminifera with shell sizes from 0.04 to $0.5 \mathrm{~mm}$ predominate among these remains of fauna. Isotropic and slightly crystallized phosphorite with point inclusions of calcite fills the internal cavities of their shells. Relic calcite preserved from phosphorite substitution sometimes forms the shell and internal partitions of sinks as well. In the scientific and technical literature, such a kind of calcite, which is located inside phosphate formations, is called 'endo calcite' and composing the cement of the rock 'exo calcite' [20, 21]. The third form of calcium carbonate is found in the form of a phosphate mineral isomorphically entering the crystal lattice. Phosphatized residues of other organisms play the subordinate role; they are the sections and nuclei of pelecites, gastropod shells up to $5 \mathrm{~mm}$ in size constituting up to $5-10 \%$ of the breed, elongated conical Pteropods up to $4-5 \mathrm{~mm}$, sea urchin needles, fish scales, etc. Cementation is often fragile; therefore, many phosphorites easily disintegrate under mechanical action, especially after soaking in water. Among organic residues, primary phosphate materials, namely, shark teeth, vertebrae and small (of a few millimetres) fragments of the marine animals' bones, are present in a small amount. Cement for phosphate is fine-grained calcite mixed with clay and phosphate-clay material. In the bottom part of the second stratum, the cement is strong crystalline; it is represented by calcite and gypsum, sometimes with a siliceous component. The results of the mineralogical study of granular phosphorite ores indicate the monotony of their composition [22-24].

The main phosphate minerals are francolite (fluorocarbonate) and calcite included in the ore by $80-90 \%$. Francolite contains on average of about $42.1 \% \mathrm{P}_{2} \mathrm{O}_{5}, 55.4 \% \mathrm{CaO}, 1.2 \% \mathrm{~F}, 2.3 \% \mathrm{Cl}, 0.6 \% \mathrm{H}_{2} \mathrm{O}$; the sum of rare elements (TR) reaches $0.03 \%$. Such ores have the following average mineral composition (weight, \%): francolite56.0; calcite-26.5; quartz-7.5; hydromica minerals and feldspars-4.0-4.5; gypsum-3.5; goethite -1.0 ; zeolite $<1.0$; organic matter-about $0.5[13,22,24]$.

The characteristics of the material composition of options with phosphate ores and slime with activated sludge are given in Table 4. 


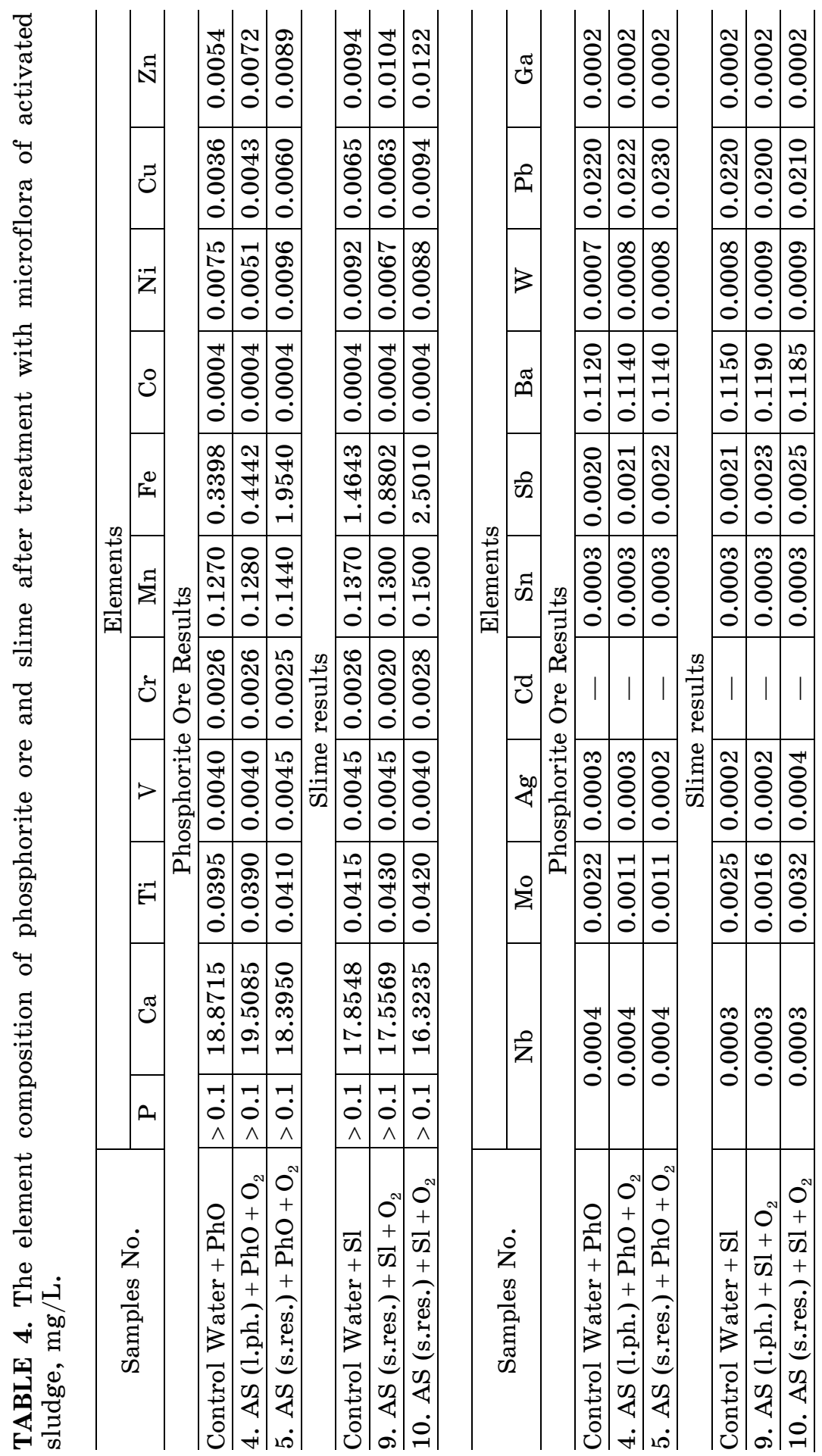


X-ray fluorescent spectral analysis of samples treated with activated sludge showed the presence in the solid phase of 25 elements, including those related to rare and scattered metals. For all samples, phosphorus is converted to a water-soluble form. The amount of calcium compounds in the solid phase ranged from 19.5085 to $16.32335 \mathrm{mg} / \mathrm{l}$ that indicates a partial transition of calcium compounds to the soluble form. In addition, the calcium content in the ore was higher $(18.8715 \mathrm{mg} / \mathrm{l})$ than in the sludge $(17.8540 \mathrm{mg} / \mathrm{l})$. With this fact, a partial dissolution of calcium compounds by water is evident. The amount of $\mathrm{Fe}$ compounds in the ore composition is minimal of $0.3398 \mathrm{mg} / \mathrm{l}$, and in the slime composition, it increases to $1.4644 \mathrm{mg} / \mathrm{l}$.

Adding a solid residue of activated sludge, the amount of $\mathrm{Fe}$ in variants 5 and 10 increases and is of 1.9544 and $2.5010 \mathrm{mg} / \mathrm{l}$, respectively, i.e., $\mathrm{Fe}$ is extracted from active sludge. For the remaining trace elements involved in the physiological reactions of living organisms, the contents of $\mathrm{Ti}, \mathrm{Mn}, \mathrm{Cu}, \mathrm{Zn}$ and partially Mo elements increase. Some decrease in the number of elements in the solid phase is noted in the variants with vanadium. Here, it is observed an ambiguous picture. If the amount of vanadium in phosphate ore increased from 0.0040 to $0.0045 \mathrm{mg} / \mathrm{l}$, for the variants with phosphate slime, its amount decreased from 0.0045 to 0.0040 $\mathrm{mg} / \mathrm{l}$, i.e., under the influence of microflora of activated sludge, partial dissolution of vanadium occurs in the slimes, but in the composition of the ore vanadium, perhaps, it is in insoluble form. Similar results are noted for $\mathrm{Ni}, \mathrm{Ag}$, Sb, Ba, and $\mathrm{Pb}$. For the others elements (Cr, Co, Ga, $\mathrm{Ge}, \mathrm{Ni}$ and $\mathrm{W}$ ) significant changes were not noted.

X-ray fluorescent analysis of phosphorites showed that its microelement composition in quantitative terms coincides with the plant one, which contains of about 75 elements of the D. I. Mendeleev periodic system, and therefore, applying this fertilizer, the plant can get all the necessary minor nutrient elements. Among the chemical elements necessary for plants, 16 ones are following as major organogenesis highlighted: carbon, oxygen, hydrogen, and nitrogen; ash elements: phosphorus, potassium, calcium, magnesium, and sulphur; trace elements: boron, molybdenum, copper, zinc, cobalt, manganese, and iron. The place of one element cannot be filled by another one, because each of them performs its own specific physiological function.

Trace elements are not random ingredients of tissues and fluids of living organisms, but components of a naturally existing ancient and very complicated physiological system that is involved in regulation of the vital functions of organisms at all development stages. Among the vital elements, there are cations: calcium $\left(\mathrm{Ca}^{2+}\right)$, sodium $\left(\mathrm{Na}^{+}\right)$, potassium $\left(\mathrm{K}^{+}\right)$, magnesium $\left(\mathrm{Mg}^{2+}\right)$, manganese $\left(\mathrm{Mn}^{2+}\right)$, zinc $\left(\mathrm{Zn}^{2+}\right)$, iron $\left(\mathrm{Fe}^{2+}\right)$, copper $\left(\mathrm{Cu}^{2+}\right)$, and cobalt $\left(\mathrm{Co}^{2+}\right)$. 


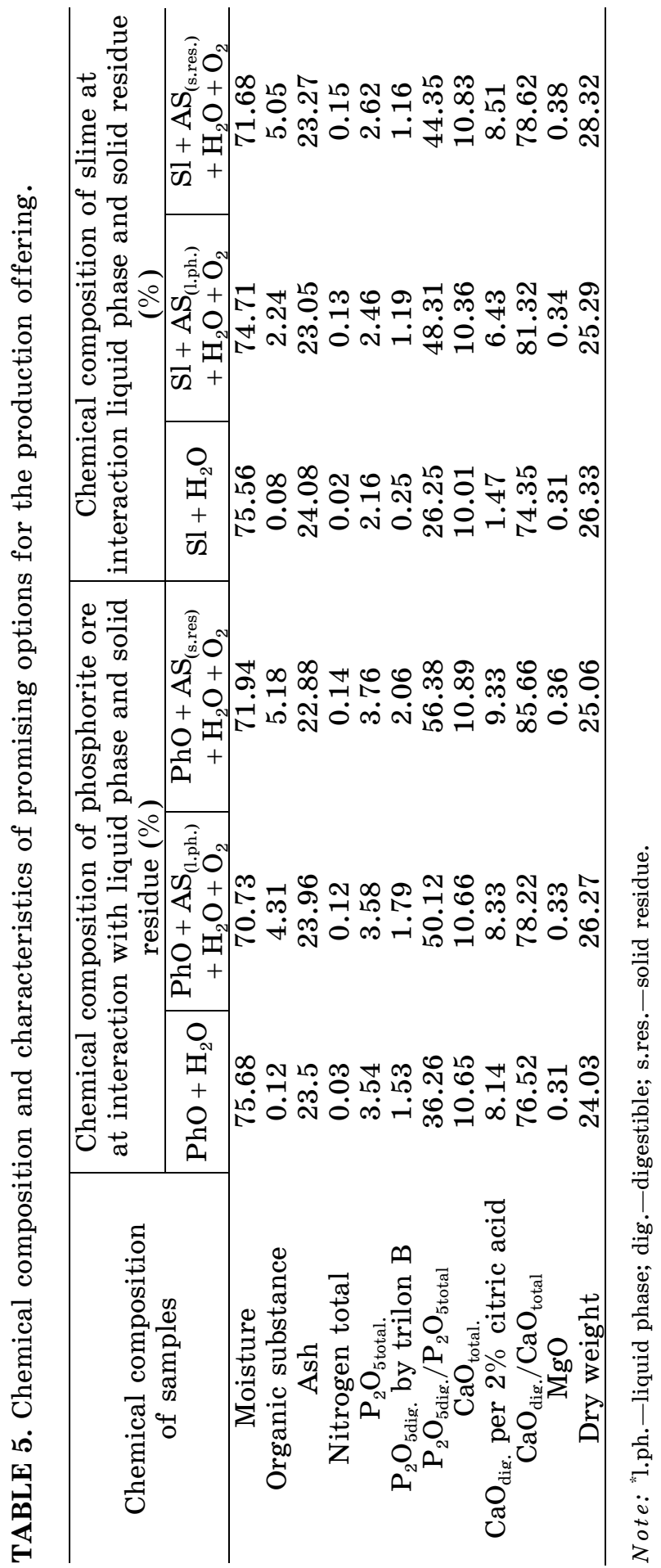


Microorganism excretions contain of a whole complex of organic compounds consisting of vitamin-like substances, humid, abscisic, gibberellic and other acids, which can be as the growth and development stimulants of plant $[25,26]$.

Thus, along with the enrichment of low-grade phosphorites with microorganisms of activated sludge and their secretions, they will be enriched with additional organic compounds and trace elements, which stimulate growth and development of plants. The results of chemical analysis of phosphorite and slime samples treated with activated sludge are presented in Table 5. Samples were taken directly from the reactors. Therefore, they have a high humidity in the range of $70-75 \%$. As we can see from Table 5, the most optimal are $4^{\text {th }}$ and $5^{\text {th }}$ variants. The amount of organic substance, nitrogen, phosphorus, calcium and magnesium in the variants with the use of a solid residue significantly exceeds the amount of these compounds in a liquid phase. However, the most interesting fact is following: in the samples with the liquid phase, there is the high activity of microorganisms in comparison with the control variants that is associated with the impact of a biogenic factor only. As a result, there was a transformation of mineral compounds of ore and slime, and these compounds turned from the insoluble form to the soluble one.

Table 6 shows the results of measuring the density of phosphorite ore and slime after treatment with activated sludge and $\mathrm{pH}$ value at the ratio of solid $(S)$ to liquid $(L)$ 1:4. The decrease in density of the medium from $1184.62 \mathrm{~g} / \mathrm{l}$ to $1092.2 \mathrm{~g} / \mathrm{l}$ is apparently due to a decrease in carbonates amount in the calcite mineral composition, in which microorganisms for their growth and development use the carbonium. Particularly intense decrease in density was noted in $4^{\text {th }}$ and $5^{\text {th }}$ variants. This circumstance allows under production conditions to use low-grade phosphorites by direct addition into aerotanks. Due to their low density, they are capable to be carried by a water stream into thickeners to separate the liquid and solid phases. The $\mathrm{pH}$ of the medium in all the studied variants was mostly neutral and changed insignificantly within 6.60-7.14. This fact confirms that the neutral and alkaline phosphorites, calcium phosphate are present in the predominant amount. Therefore, in the biochemical processing of the household and industrial effluents in the amount of 55-60 thousand $\mathrm{m}^{3}$ /day (Fig. 1), phosphorite slimes can be loaded into primary clarifiers, because, due to their low density and fine dispersion, they can freely transfer to sludge accumulators.

Thus, we carried out the pilot test of phosphorite slime at the treatment plant in Zarafshan city, where 4 tons of phosphorite slime were loaded into the primary clarifiers. 
400 N. A. DONIYAROV, I. A. TAGAEV, M. N. MURATOVA, L. S. ANDRIYKO

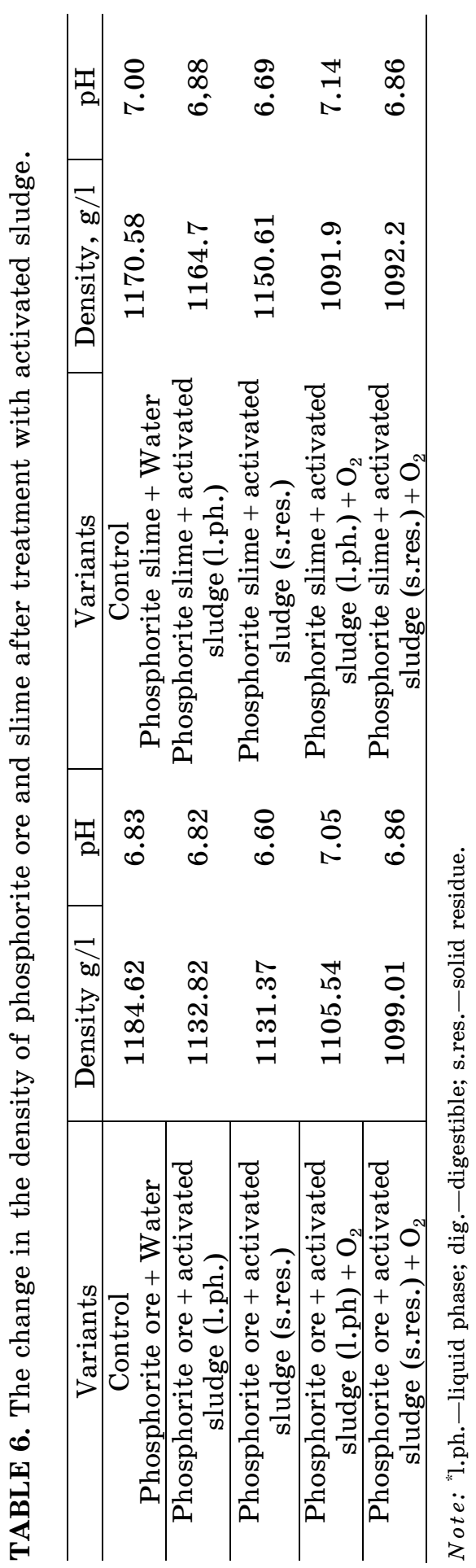




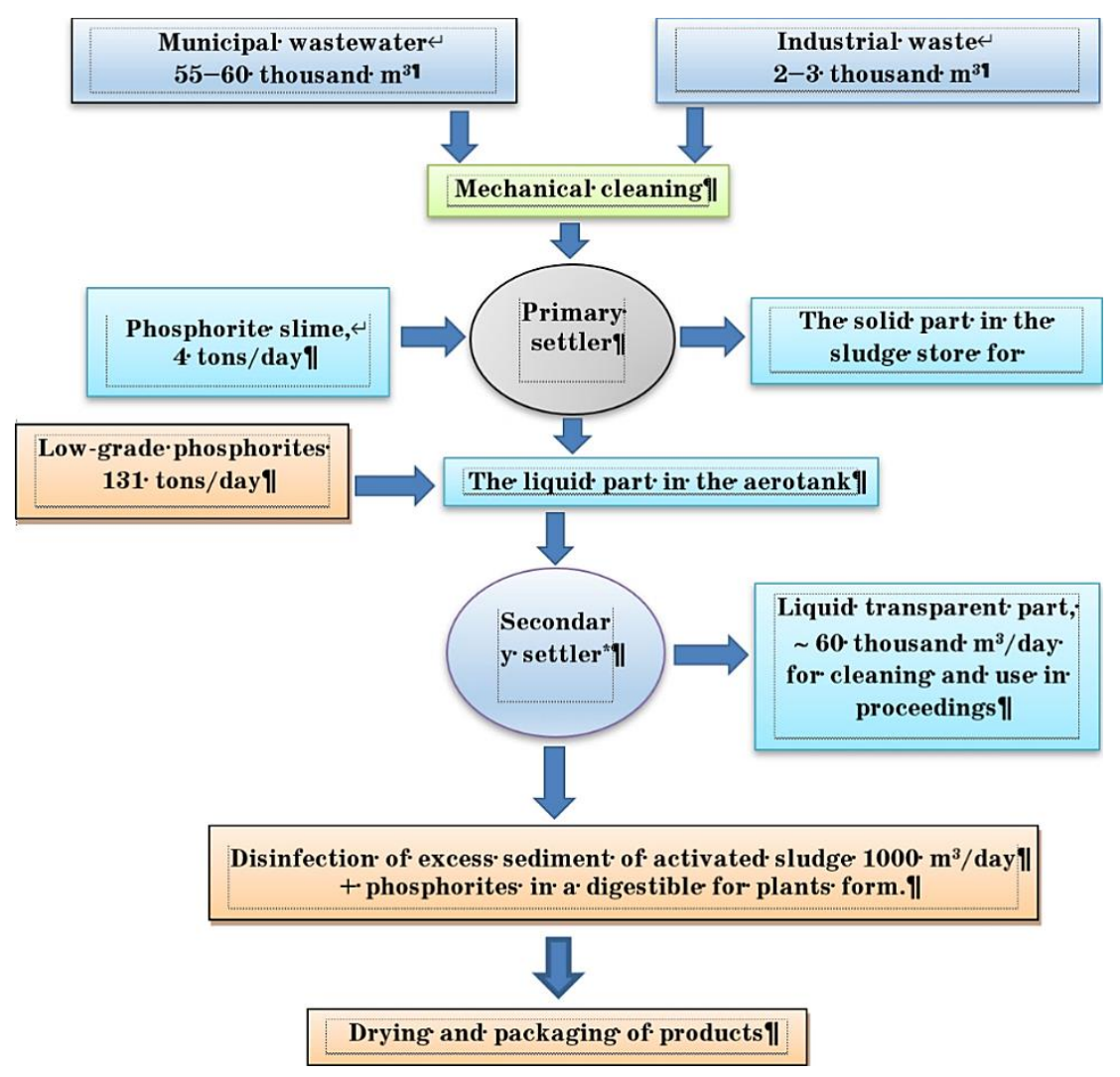

Fig. 1. The basic process flow diagram of obtaining an organic fertilizer ("coagulants can be added).

After 24 hours, they were pumped out to the silt reservoirs. Then, they were irrigated with excess activated sludge from aerotanks. Considering the daily volume of the biochemical treatment plants, it is possible to adjust the supply of phosphorite slime. In this case, daily up to 12 tons of phosphorite slime can be loaded into the primary clarifiers of the Zarafshan treatment plant.

Low-grade phosphorites are recommended to be loaded into aerotanks, since they have a higher density (Table 7). By a flow of supplied air, phosphorites with a higher density will be easily leached from the aerotanks and get into the secondary clarifiers. Then, the extraction of condensed sediments will be made from secondary clarifiers. Every twenty-four hours, about 275 tons of low-grade phosphorites can be loaded into aerotanks. Thus, up to 90 thousand tons of phosphorites with a content of $8-10 \% \mathrm{P}_{2} \mathrm{O}_{5}$ (Fig. 1) can be recycled per year, followed by the finished-product output. 


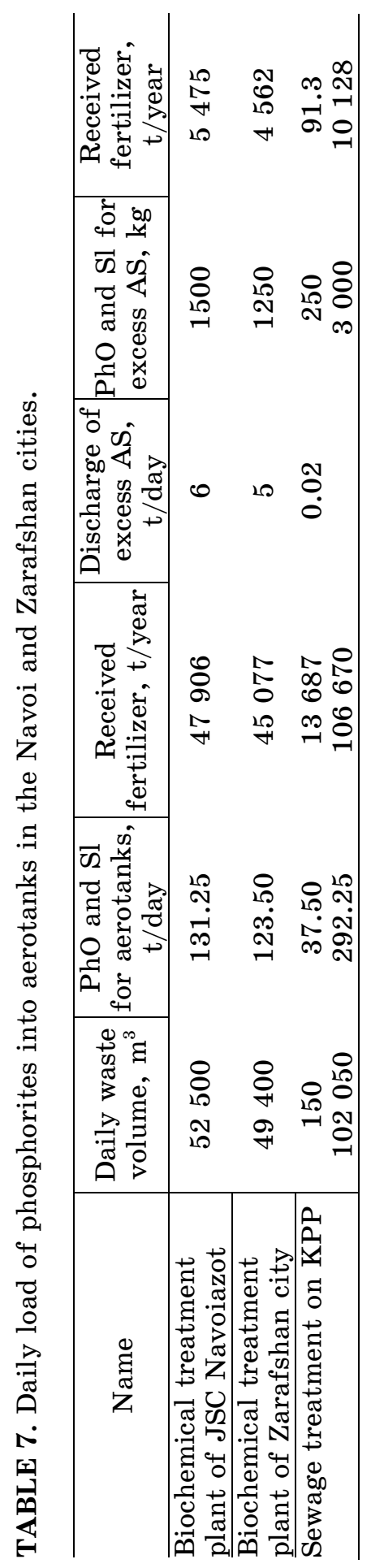


Obtained after primary and secondary clarifiers, solid condensed sediments with low-grade phosphorites and slime added to them will have up to $18-22 \% \mathrm{P}_{2} \mathrm{O}_{5}, 12-14 \%$ nitrates and nitrites, $4-5 \% \mathrm{~K}_{2} \mathrm{O}$, and $\mathrm{CaO}$ and $\mathrm{MgO}$ are digestible by plants, together with the accompanying set of all trace elements.

In this way, it is possible to obtain the high-quality new fertilizer, referred to as organic-mineral nitrogen-phosphorus polymicroelement fertilizer [26].

In all major cities of the Uzbekistan Republic, there are the biochemical treatment plants of municipal waste. It is not known how excess activated sludge is recycled at these plants. Therefore, application of low-grade phosphorites at these plants will allow us to obtain the organic fertilizer. There would be a real opportunity to provide phosphorus fertilizers in all Republic regions, without spending additional funds on the import of mineral phosphoruscontaining fertilizers.

For the daily load of aerotanks of municipal waste-treatment plants in the Navoi region, calculations were made (Table 7). It was shown that, for the daily load, with a ratio of phases $S: L=1: 4$, up to 92 thousand tons of phosphorus-containing organic-mineral fertilizers per year can be obtained. At KPP NMMC, slimes are released as waste with a content of up to $10.5 \% \mathrm{P}_{2} \mathrm{O}_{5}$. Such slime wastes were accumulated in the first slime storage facility (dried out) with $16730 \mathrm{~m}^{3}$, in the second one, with $3000 \mathrm{~m}^{3}$, in the third one, with about $7000 \mathrm{~m}^{3}$. Considering the size of the slime particles and their ability to be in the peptized state for a long period of time, it is proposed to add these slimes into aerotanks to activate by the microflora of biochemical treatment plant, since they will not linger in them.

Thus, the Navoi region with the effective use of low-grade phosphorite ores and slimes at KPP NMMC can satisfy its regional needs for high-quality organic-mineral fertilizers, but also sell the finished product to third-party organizations as well.

\section{CONCLUSION}

Based on the provision of agricultural production of the Uzbekistan Republic with own phosphate fertilizers by $30-32 \%$, a radically new solution was found for obtaining a new type of phosphoruscontaining fertilizer, where the microflora of activated sludge from biochemical treatment plants is used for transforming the insoluble low-grade phosphorite in organic-mineral nitrogen-phosphorus polymicroelement fertilizer. As a result of studying the degree of production load at the biochemical treatment plants of Navoi and Zarafshan cities, it is proposed addition of the low-grade phospho- 
rites at the ratio of the solid-to-liquid phases $S: L=1: 4$ and, in this way, to get the new type of fertilizer without prejudice to the sewage treatment plant.

For all agro-industrial regions of the Uzbekistan Republic, it is recommended to use this technology to ensure their own needs in phosphorus-containing organic fertilizers.

\section{REFERENCES}

1. Sh. S. Namazov, U. Sh. Temirov, and N. H. Usanbayev, International Jour nal of Innovative Technology and Exploring Engineering, 8, No. 2: 2278 (2019); doi:10.35940/ijitee.L2529.1081219

2. D. Sh. Sherkuziev, Uzb. Chem. J., 3: 63 (2008) (in Russian).

3. A. Zh. Allamuratova, A. U. Erkaev, Z. K. Toirov, and A. M. Reimov, Chemical Industry, 88, No. 3: 109 (2011) (in Russian).

4. N. M. Golub, Bulletin of the University of Brest, 1: 14 (2011) (in Russian).

5. N. A. Doniyarov and I. A. Tagaev, Mining Bulletin of Uzbekistan, 4, No. 75: 912018 (2018) (in Russian).

6. L. F. Melnikov, Organomineral Fertilizers: Theory and Practice of Their Production and Use (St. Petersburg: Publishing House Polytechnic University: 2007) (in Russian).

7. D. Sh. Sherkuziev, Kh. M. Kanoatov, M. Kh. Dadamirzaev, D. A. Saribaeva, and Y. G. Yokubzhanova, Technique. Technology. Engineering, 2: 101 (2017) (in Russian).

8. U. Sh. Temirov, A. M. Reymov, Sh. S. Namazov, and N. X. Usanbaev, Universum: Technical Sciences, 8, No. 29: 43 (2016) (in Russian).

9. N. A. Doniyarov, I. A. Tagaev, I. N. Murodov, and Sh. A. Muratov, Mining Bulletin of Uzbekistan, 1, No. 72: 52 (2018) (in Russian).

10. N. M. Shchegolkova, G. S. Krasnov, A. A. Belova et al., Front Microbiol., 18, No. 7: 90 (2016); https://doi.org/10.3389/fmicb.2016.00090

11. R. Teodosieva and D. Bojinova, Braz. J. Chem. Eng., 33, No. 1: 1 (2016); http://dx.doi.org/10.1590/0104-6632.20160331s00003267

12. D. Bojinova, R. Teodosieva, and K. Nedialkova, J. Univ. Chem. Technol. Metall., 43: 383 (2008).

13. A. I. Smirnov, The Material Composition and Conditions of Formation of the Main Types of Phosphorites (Moscow: Nedra: 1972) (in Russian).

14. M. M. Vinnik, L. M. Erbanova, P. M. Zaitsev et al., Methods of Analysis of Phosphate Raw Materials, Phosphate and Complex Fertilizers, Feed Phosphates (Moscow: Khimiya: 1975) (in Russian).

15. GOST 26714-85. Organic Fertilizers. Method for Determination of Ash Content (Moscow: 1985) (in Russian).

16. GOST 26712-94. Organic Fertilizers. General Requirements for Methods of Analysis (Minsk: 1995) (in Russian).

17. GOST 27980-88. Organic Fertilizers. Organic Determination Method (Moscow: 1989) (in Russian).

18. A. V. Skalny, Chemical Elements in Human Physiology and Ecology (Moscow: ONIKS-21 Century-Mir: 2004) (in Russian).

19. B. E. Sultanov, Z. M. Tursunova, Sh. S. Namazov, A. U. Erkaev, and 
B. M. Beglov, Uzb. Chem. J., 4: 10 (2002) (in Russian).

20. T. Sh. Shayakubov, V. Y. Ilyashenko, B. S. Boyko, N. S. Kudryashov, and U. T. Turanov, Soviet Geology, 7: 3 (1982) (in Russian).

21. T. Sh. Shayakubov, G. I. Malmatin, A. Z. Yuldashev et al., Phosphorite Deposits of the Mesozoic and Cenozoic of Uzbekistan. Geological Problems of Phosphorite Accumulation (Moscow: Nauka: 1987) (in Russian).

22. B. M. Beglov and Sh. R. Namazov, Phosphorites of the Central Kyzyl Kum and Their Processing (Tashkent: 2013) (in Russian).

23. A. L. Olifson and S. V. Makhov, Research in the Field of Complex Processing of Phosphate Raw Materials. A Comparative Analysis of the Work of Researchers for 1970-2012 (Moscow: 2015) (in Russian).

24. Kh. Ch. Mirzakulov, N. V. Volinskova, G. Eh. Melikulova, and I. I. Usmanov, Universum: Technical Sciences, Iss. 2 (59): 89 (2019) (in Russian); https://7universum.com/ru/tech/archive/item/6952

25. A. I. Netrouzov, E. A. Bonch-Osmolovskaya, and V. M. Gorlenko, Ecology of Microorganisms (Moscow: Akademiya: 2004) (in Russian).

26. E. P. Pakhnenko, Sewage Sludge and Other Unconventional Organic Fertilizers (Moscow: BINOM-MSU: 2015) (in Russian). 